\title{
EFEKTIFITAS KONSENTRASI EKSTRAK REBUNG BAMBU (Gigantochloa nigrociliata) SEBAGAI ANESTESI TERHADAP KELANGSUNGAN HIDUP BENIH IKAN LELE SANGKURIANG (Clarias gariepinus)
}

\section{THE EFFECTIVE CONCENTRATION EXTRACT BAMBOO SHOOTS (Gigantochloa nigrociliata) AS AN ANESTHETIC AGAINST THE VIABILITY SEED OF SANGKURIANG CATFISH (Clarias gariepinus)}

\author{
Fazril Saputra $^{1 *}$, Sukardi $^{2}$, Eri Safutra ${ }^{1}$, Mahendra ${ }^{1}$ \\ ${ }^{1}$ Jurusan Akuakultur, Fakultas Perikanan dan Ilmu Perikanan, Universitas Teuku Umar \\ ${ }^{2}$ Jurusan Perikanan, Fakultas Perikanan dan Ilmu KelautanUniversitas Teuku Umar \\ *Koresponden: fazrilsaputra@utu.ac.id
}

\begin{abstract}
ABSTRAK
Tujuan dari penelitian ini yaitu mengetahui pengaruh ekstrak rebung bambu terhadap tingkat kelangsungan hidup benih ikan lele sangkuriang dan mengetahui kosentrasi ekstrak rebung bambu yang terbaik terhadap transportasi sistem basah. Rancangan penelitian yang digunakan dalam penelitian ini adalah rancangan acak lengkap (RAL). Parameter yang diamati meliputi tingkat kelangsungan hidup dan kualitas air. Hasil penelitian uji toksisitas $\left(\mathrm{LC}_{50}\right)$ didapatkan nilai $\mathrm{LC}_{50}-96$ jam adalah 77,50 ppm yang menyebabkan kematian minimal 50\% pada hewan uji, waktu pemingsanan ikan terbaik yaitu 17,92 menit pada perlakuan 800 ppm, waktu ikan sadar terbaik yaitu 3,66 pada perlakuan 200 ppm dan kelangsungan hidup terbaik adalah $100 \%$ pada perlakuan kontrol. Hasil penelitian ini menunjukan bahwa pemberian ekstrak rebung bambu dapat memberikan dampak yang positif terhadap parameter uji toksisitas $\left(\mathrm{LC}_{50}\right)$, waktu pemingsanan ikan, waktu sadar ikan dan tingkat kelangsungan hidup $(\mathrm{P}>0,05)$.
\end{abstract}

Kata kunci: rebung bambu, kelangsungan hidup, Clarias gariepinus

\begin{abstract}
The purpose of this research was to know the effect of bamboo shoot extract on the survival rate of sangkuriang catfish seeds and to know the concentration of bamboo shoot extract is best to transport wet system. Design of research used in this study was a randomized complete design. Toxicity tests using a concentration of treatment was determined i.e. the 0 ppm, 200 ppm, $400 \mathrm{ppm}$ and $800 \mathrm{ppm}$. The observed parameters include was the survival rate and quality of water. Test results of toxicity (LC50) obtained the value of LC50-96 hours is $77.50 \mathrm{ppm}$ causing death of at least $50 \%$ of the test animals, time passed out the best fish namely 17.92 minutes at $800 \mathrm{ppm}$ treatment, time conscious fish best i.e. 3.66 minutes at $200 \mathrm{ppm}$ treatment and survival of the best is $100 \%$ in the control treatment.The results showing of extracts bamboo shoots can provide a positive impact against the parameter test toxicity (LC50), time conscious of time passing out fish, the fish and the survival rate $(\mathrm{P}>0.05)$.
\end{abstract}

Keywords: bamboo shoots, survival rate, Clarias gariepinus

\footnotetext{
*Fakultas Perikanan dan Ilmu Kelautan, Universitas Teuku Umar

Korespondensi : Jurusan Akuakultur, Fakultas Perikanan dan Ilmu Kelautan, Universitas Teuku Umar, Kampus UTU Meulaboh, Alue Peunyareng 23615, Telp: +62 85260930305, email: fazrilsaputra@utu.ac.id
} 


\section{PENDAHULUAN}

Ikan lele (Clarias gariepinus) merupakan salah satu hasil perikanan budidaya yang menempati urutan teratas dalam jumlah produksi yang dihasilkan. Selama ini ikan lele menyumbang lebih dari $10 \%$ produksi perikanan budidaya nasional dengan tingkat pertumbuhan mencapai 17 hingga $18 \%$. Departemen Kelautan dan Perikanan (DKP), menetapkan ikan lele sebagai salah satu komoditas budidaya ikan air tawar unggulan di Indonesia. Tingginya angka konsumsi dalam negeri dan terbuka nya pangsa pasar ekspor, memastikan komoditas ikan air tawar ini menjadi penyumbang devisa negara yang sangat menjanjikan. Ikan lele merupakan komoditas perikanan budidaya air tawar yang mempunyai tingkat serapan pasar cukup tinggi, baik di pasar dalam negeri maupun ekspor. Peningkatan produksi ikan lele di Indonesia didorong oleh tingginya permintaan terhadap ikan lele, baik benih maupun ikan lele konsumsi. Tingginya permintaan terhadap ikan lele baik benih maupun ikan lele konsumsi tidak terlepas dari program pemerintah yang mencanangkan Indonesia sebagai produsen terbesar ikan konsumsi atau hasil budidaya dunia tahun 2015 .

Masalah yang dihadapi dalam proses pengangkutan ikan hidup adalah bagaimana menekan aktivitas metabolisme ikan agar kebutuhan oksigen maupun hasil metabolismenya sekecil mungkin. Salah satu cara transportasi dan perdagangan ikan dalam kondisi hidup yang telah banyak dilakukan dan menjadi alternatif pilihan yang tepat jika kondisi optimalnya dikendalikan yaitu penggunaan suhu rendah yang dapat dilakukan dengan penurunan suhu secara bertahap maupun secara langsung (Setiabudi et, al. 1995). Cara yang umum dilakukan untuk menekan aktivitas metabolisme adalah dengan pendinginan, yaitu dengan penambahan es dalarn media angkut atau dengan penambahan senyawa kimiawi yang bersifat anaestetik (Rahardja, 1995).

Salah satu cara menekan metabolisme dan aktivitas ikan selama transportasi adalah menambahkan bahan anestesi ke dalam media pengangkutan. Salah satu obat bius yang biasa digunakan untuk mengurangi stress dan kematian pada transportasi ikan hidup adalah bahan alami (Yanto, 2012). Pembiusan dengan menggunakan bahan anestesi bertujuan untuk memperpanjang waktu transportasi dengan menekan metabolisme dan aktivitas ikan serta mengurangi resiko ikan mengalami stres yang dapat berakibat pada kematian. Bahan anestesi dapat berupa bahan alami dan bahan kimia sintetik (Septiarusli et.al, 2012). Salah satu bahan anestesi alami diantaranya adalah rebung bambu (Gigantochloa nigrociliata). Senyawa aktif yang terkandung dalam Gigantochloa nigrociliata yang dapat menyebabkan keracunan pada ikan adalah kelompok senyawa asam sianida ( $\mathrm{HCN})$. Pada rebung bambu mengandung banyak minyak yang di dalamnya terkandung senyawa Sianogenik glukosida yang disebut Asam Sianida $(\mathrm{HCN})$ yaitu alkoloid yang bersifat racun. Selain itu, rebung bambu banyak terdapat di berbagai wilayah di Indonesia, namun sampai saat ini belum banyak dimanfaatkan secara optimal terutama dalam bidang perikanan. Tujuan dari penelitian ini yaitu: Mengetahui pengaruh ekstrak rebung bambu terhadap tingkat kelangsungan hidup benih ikan lele sangkuriang (Clarias gariepinus) dan mengetahui konsentrasi ekstrak rebung bambu yang terbaik terhadap lama pembiusan pada ikan lele sangkuriang (Clarias gariepinus).

\section{METODE PENELITIAN}

Penelitian ini dilaksanakan di Laboratorium Hayati, Fakultas Matematika dan Ilmu Pengetahuan Alam Unsyiah (FMIPA Unsyiah) dan Hatchery Fakultas Perikanan dan Ilmu Kelautan Universitas Teuku Umar dari bulan November hingga Desember 2016.

\section{Prosedur Penelitian}

Rancangan Penelitian

Rancangan penelitian yang digunakan dalam penelitian ini adalah rancangan acak lengkap (RAL). Penelitian di lakukan melalui tiga tahap uji, yaitu: uji pendahuluan, uji toksisitas $\left(\mathrm{LC}_{50}\right)$, dan uji perlakuan. Pada uji pendahuluan menggunakan satu kontrol dan tujuh konsentran yaitu : $\mathrm{K}=0 \mathrm{ppm}, \mathrm{P} 1=0,01$ ppm; $\mathrm{P} 2=0,1 \mathrm{ppm} ; \mathrm{P} 3=1 \mathrm{ppm} ; \mathrm{P} 4=10$ ppm; $\mathrm{P} 5=100$ ppm; $\mathrm{P} 6=500 \mathrm{ppm}$ dan $\mathrm{P} 7=$ $1000 \mathrm{ppm}$, pada uji toksisitas menggunakan satu control dan tiga perlakuan yaitu: Kontrol $=0$ ppm; $\mathrm{P} 1=200 \mathrm{ppm} ; \mathrm{P} 2=400 \mathrm{ppm} ; \mathrm{dan}$ $\mathrm{P} 3=800 \mathrm{ppm}$, dan pada uji perlakuan 
menggunakan tiga perlakuan, satu kontrol dengan masing-masing 3 kali ulangan.

\section{Ekstraksi Bahan Anestesi}

Proses ekstraksi diawali dengan pembersihan rebung bambu dari sisa-sisa kulit yang masih tersisa. Pembersihan dilakukan segera setelah rebung bambu dipanen, dan dilakukan dengan hati-hati untuk mengurangi terjadinya proses lisis (peristiwa pecahnya sel karena kerusakan membran/selaputnya) kandungan rebung bambu. Rebung bambu yang telah bersih kemudian dihaluskan dengan menggunakan parutan. Rebung bambu yang telah halus akan dipotong kecil-kecil lalu ditimbang dengan menggunakan neraca analitik.

Sebanyak 1,5 Kg Rebung bambu halus ditimbang dan direndam dalam 2 liter larutan etanol 96\% selama 48 jam. Proses ini dilakukan secara berulang hingga bahan pelarut (etanol) tidak mengalami perubahan warna saat ditambah dengan potongan Rebung bambu. Hasil ekstraksi etanol selanjutnya dipekatkan dengan menggunakan vacuum rotary evaporator.

\section{Persiapan Wadah}

Wadah yang digunakan dalam penelitian uji pendahuluan adalah toples transparan yang berjumlah 24 unit berkapasitas 10 liter. Sebelum digunakan wadah dibersihkan terlebih dahulu dengan menggunakan kaporit dan air hangat, kemudian diisi air, Selanjutnya dilakukan penambahan konsentrasi ekstrak rebung bambu sesuai dengan perlakuan yang sudah ditentukan pada wadah yang telah dipersiapkan. Sedangkan pada uji toksisitas $\left(\mathrm{LC}_{50}\right)$ menggunakan toples transparan berjumlah 12 unit dan pada uji transportasi menggunakan plastik packing berjumlah 12 unit dengan kapasitas 20 liter.

\section{Ikan Uji}

Benih ikan lele sangkuriang yang didatangkan dari UPTD-BAT Jantho yang telah diaklimatisasi selama 7 hari, selanjutnya diambil ikan yang seragam di kolam pemeliharaan dengan jumlah masing-masing media percobaan adalah 10 ekor/ 5 liter air. Ikan sampel adalah benih ikan lele sangkuriang dengan panjang total rata-rata 6-8 $\mathrm{cm}$ dan berat rata-rata 0-1 gram yang menjadi sampel uji.

\section{Uji Pendahuluan \\ Uji pendahuluan dilakukan untuk} memperoleh konsentrasi ambang bawah (LC50-48 jam) yaitu konsentrasi tertinggi dimana hewan uji tidak mengalami kematian dalam waktu dedah 48 jam, dan konsentrasi ambang atas (LC100-24 jam) yaitu konsentrasi terendah yang menyebabkan mortalitas $100 \%$ dalam waktu 24 jam. Pelaksanaan uji pendahuluan ini menggunakan media uji berdasarkan pada deret logaritma, yaitu 0 ppm; $0,01 \mathrm{ppm} ; 0,1$ ppm; 1 ppm; 10 ppm; 100 ppm; 500 dan 1000 ppm. Dalam uji pendahuluan ini digunakan 10 ekor ikan uji yang dibagi menjadi 8 kelompok. Lama uji pendahuluan ini dilaksanakan selama dua hari (48 jam).

\section{Uji toksisitas}

Uji toksisitas dilakukan untuk mengetahui tingkat kematian (mortalitas) ikan hingga 50\% dalam waktu 96 jam. Pengamatan ikan ini menurut seri waktu yaitu: 6 jam; 12 jam; 24 jam; 48 jam; 72 jam; 96 jam. Ikan uji yang telah mati segera dibuang tanpa pergantian ikan. Pengujian ini dilakukan terhadap 7 kelompok konsentrasi dan 1 kelompok kontrol. Uji toksisitas ini dilakukan selama 4 hari untuk mengetahui toksisitas dari ekstrak rebung, kemudian dilakukan perhitungan dengan analisa probit sehingga diperoleh Nilai $\mathrm{LC}_{50}-96$ jam sebesar 77,50 ppm.

\section{Uji Perlakuan}

Uji perlakuan dilakukan dalam toples bervolume 10 liter dengan pemberian konsentrasi ekstrak rebung bambu yang berbeda dan selanjutnya dicatat lama waktu pingsan ikan setelah pemberian ekstrak rebung bambu lalu setelah itu dicatat lama waktu ikan sadar.

\section{Parameter Uji}

Parameter yang diamati pada penelitian ini adalah respon morfologis, tingkat kelangsungan hidup dan kualitas air.

\section{Analisis Data}

Data yang diperoleh adalah data tingkah laku ikan, lama waktu untuk pingsan, lama waktu pingsan kelangsungan hidup dan kualitas air. Data yang diperoleh selanjutnya dianalisis ragam dengan menggunakan 
Analysis of Varience (ANOVA) untuk mengetahui pengaruh perlakuan yang diberikan tingkah laku ikan, lama waktu untuk pingsan, lama waktu pingsan, lama waktu sadar, kelangsungan hidup dan kualitas air. Data-data tersebut disajikan dalam bentuk grafik dan tabel. Jika dari analisis ragam diketahui bahwa perlakuan menunjukkan pengaruh yang berbeda nyata atau berbeda sangat nyata maka untuk menentukan perbedaan antar perlakuan dilanjutkan dengan Uji Beda Nyata Terkecil (BNT) (Rochiman, 1989).

\section{HASIL DAN PEMBAHASAN}

Tabel 1 menunjukan hasil uji fitokimis, senyawa yang terkandung di dalam ekstrak rebung bambu yaitu senyawa alkaloid, steroid, flavonoid dan fenol. Hal ini sesuai dengan penelitian Sujarwo, et.al., (2010) yaitu rebung bambu mengandung nutrisi yang tinggi seperti vitamin, asam amino, mineral $\mathrm{Zn}, \mathrm{Mn}, \mathrm{Mg}, \mathrm{Ni}$, Co dan HCN dalam kadar rendah yang bersifat alkaloid (racun). Rebung bambu juga diketahui mengandung senyawa steroid, fitosterol, flavonoid dan phenol (Choudhury, et.al., 2012).

Adapun senyawa aktif pada tanaman tersebut yang bersifat anestetik adalah $\mathrm{HCN}$ yang terkandung di dalam alkaloid, senyawa ini bersifat melemahkan sistem metabolisme pada ikan sehingga tidak sadarkan diri. Dengan demikian senyawa $\mathrm{HCN}$ yang terkandung dalam rebung bambu bisa dijadikan untuk pembiusan (anestesi) dalam kegiatan transportasi ikan.

Uji pendahuluan bertujuan untuk menetapkan konsentrasi ambang atas dan ambang bawah yang dilakukan dengan cara mengamati mortalitas ikan lele sangkuriang (Clarias gariepinus). Uji ini dilakukan menggunakan 8 konsentrasi yaitu : 0,01 ppm; 0,1 ppm; $1 \mathrm{ppm} ; 10 \mathrm{ppm} ; 100 \mathrm{ppm} ; 500 \mathrm{ppm}$; $1000 \mathrm{ppm}$ dan 1 kontrol ( 0 ppm) dengan 3 kali pengulangan pada 24 wadah uji yang masing-masing diisi 10 ekor ikan.

Berdasarkan data pada tabel 2, bahwa rebung bambu berbahan aktif alkaloid jenis HCN (asam sianida) memiliki nilai ambang atas $1000 \mathrm{ppm}$. Konsentrasi tersebut merupakan konsentrasi tertinggi dimana seluruh ikan uji (100\%) mati dalam waktu 24 jam. Nilai ambang bawah adalah 0 ppm. Konsentrasi tersebut merupakan konsentrasi terendah dimana ikan uji masih hidup seluruhnya (100\%) dalam waktu 48 jam.

Menurut Husni (2010), uji pendahuluan dilakukan untuk menentukan batas kisaran kritis (critical range test) yang menjadi dasar dari penentuan konsentrasi yang digunakan dalam uji lanjutan atau uji toksisitas sesungguhnya, yaitu konsentrasi yang dapat menyebabkan kematian terbesar mendekati $50 \%$ dan kematian terkecil mendekati $50 \%$.

\section{Toksisitas Rebung Bambu ( $\left.\mathrm{LC}_{50}\right)$}

Uji toksisitas dilakukan menggunakan 3 konsentrasi dan 1 kontrol yang didapat dengan cara menguraikan secara logaritma nilai ambang atas dan ambang bawah yang diperoleh dari uji pendahuluan. Setelah dilakukan perhitungan, maka didapatkan konsentrasi yang digunakan pada uji lanjut adalah: Kontrol $=0$ ppm, P1 $=200$ ppm, P2 $=400 \mathrm{ppm}$ dan $\mathrm{P} 3=800$. Hasil uji lanjut ini menunjukkan jumlah mortalitas ikan dalam waktu 96 jam.

11. Hasil uji fitokimia sebagai berikut:

\begin{tabular}{lccc}
\hline Kandungan Kimia & Reagen & $\begin{array}{c}\text { Sampel Segar } \\
\text { Rebung Bambu }\end{array}$ & Hasil Pengamatan \\
\hline Alkaloid & Mayer & + & Putih \\
& Wagner & - & Endapan Coklat \\
Steroid & Dragendorff & - & Merah \\
Terpenoid & Uji Liebermann & + & Merah \\
Saponin & Uji Liebermann & - & Merah \\
Flavonoid & Pengocokan & - & Berbusa \\
Fenol & $0,5 \mathrm{~g} \mathrm{Mg} \mathrm{dan} \mathrm{HCl}$ & + & Kuning \\
\hline
\end{tabular}

Keterangan: (+) menunjukkan hasil positif dan (-) menunjukkan hasil negatif. 
Tabel 2. Tingkat kematian pada uji pendahuluan

\begin{tabular}{cccc}
\hline \multirow{2}{*}{ Perlakuan } & \multicolumn{2}{c}{ Jam Ke- } & \multirow{2}{*}{ Mortalitas $(\%)$} \\
\cline { 2 - 3 } & 24 & 48 & 0 \\
0,01 & 0 & 0 & 0 \\
0,1 & 0 & 0 & 0 \\
1 & 0 & 0 & 0 \\
10 & 0 & 0 & 0 \\
100 & 0 & 0 & 0 \\
500 & 0 & 0 & 63,33 \\
1000 & 14 & 5 & 100 \\
\hline
\end{tabular}

Setelah melakukan uji toksisitas, dilanjutkan dengan analisa probit untuk mengetahui nilai $\mathrm{LC}_{50-96}$ jam, yaitu nilai konsentrasi dimana $50 \%$ dari ikan uji mati dalam waktu pendedahan $96 \mathrm{jam}$. Berdasarkan perhitungan tersebut, didapatkan nilai $\mathrm{LC}_{50}-96$ jam adalah $77,50 \mathrm{ppm}$. Tingkat daya racun berdasarkan nilai $\mathrm{LC}_{50-96}$ jam suatu bahan aktif yang bersifat racun pada ikan dibedakan menjadi beberapa kriteria yang dapat dilihat pada tabel 3.

Nilai LC50 merupakan konsentrasi suatu bahan yang menyebabkan kematian minimal $50 \%$ pada hewan uji. Berdasarkan kriteria tersebut, dapat disimpulkan bahwa tingkat daya racun dalam kandungan ekstrak rebung bambu berada pada kisaran $10-100$ ppm, yaitu memiliki tingkat racun sedang.

Berdasarkan hasil rata-rata mortalitas bioindikator pada Gambar 1, nampak bahwa semakin tinggi konsentrasi ekstrak rebung bambu yang diberikan maka akan semakin banyak jumlah bioindikator benih ikan lele sangkuriang yang mati. Hasil perhitungan ANOVA menunjukan ekstrak rebung bambu berpengaruh sangat nyata terhadap mortalitas benih ikan lele sangkuriang. Berdasarkan hasil uji lanjut Beda Nyata Terkecil (BNT) pada selang kepercayaan $95 \%$, diperoleh hasil berbeda sangat nyata antara perlakuan P1 dengan perlakuan kontrol selanjutnya diperoleh hasil berbeda sangat nyata antara perlakuan P2 dengan perlakuan Kontrol dan P3 dengan perlakuan kontrol, serta terdapat hasil tidak berbeda nyata antara perlakuan P2 dengan perlakuan $\mathrm{P} 1$, perlakuan $\mathrm{P} 3$ dengan Perlakuan P1 dan perlakuan P3 dengan perlakuan $\mathrm{P} 2$.

\section{Respon Morfologis}

Ikan yang telah diaklimatisasikan kemudian diuji menggunakan ekstrak rebung bambu dan dilakukan pengamatan. Pengamatan respon morfologi ikan dilakukan setiap 10 menit, dimulai dari menit ke-0 hingga ikan pingsan. Ikan yang pingsan ditandai dengan posisi tubuh ikan roboh dan operculum insang bergerak dengan lambat. Perlakuan yang diberikan adalah perbedaan konsentrasi ekstrak rebung bambu sebagai bahan anestesi yaitu 0 ppm, 200 ppm, 400 ppm dan 800 ppm. Hasil pengamatan terhadap tingkah laku ikan pada setiap perlakuan dapat dilihat pada Tabel 2 .

Tabel 4 menunjukkan bahwa perlakuan ekstrak rebung bambu dengan konsentrasi 800 ppm memberikan pengaruh yang lebih cepat dibandingkan perlakuan pucuk yang lain. Hal tersebut dapat dilihat dari waktu yang dibutuhkan ikan uji untuk mencapai tahap pingsan yang lebih cepat dibandingkan perlakuan 200 dan 400 ppm. Pada perlakuan 200 ppm ikan dimasukkan ke dalam media anestesi dalam kondisi normal. Ikan mengalami kehilangan keseimbangan pada menit ke 16-20 lalu ikan tidak bergerak di dasar wadah (stationer) dan menit 21-25 dibarengi dengan operculum ikan melambat selanjutnya ikan pingsan pada menit 31-35.

Tabel 3. Tingkat Daya Racun Berdasarkan Nilai $\mathrm{LC}_{50}-96$ jam

\begin{tabular}{cc}
\hline Nilai LC 50 $_{5}-96$ jam & Tingkat Daya Ra \\
\hline$<1 \mathrm{ppm}$ & Sangat Tinggi \\
$1-10 \mathrm{ppm}$ & Tinggi \\
$10-100 \mathrm{ppm}$ & Sedang \\
$>100 \mathrm{ppm}$ & Ringan
\end{tabular}

Sumber: APHA, 1998 
Pada perlakuan 400 ppm ikan yang dimasukkan dalam keadaan normal langsung berinteraksi ditandai dengan pergerakan aktif, pada menit 6-10 ikan mulai kehilangan keseimbangan dan pada menit selanjutnya 11-15 ikan mulai stationer dibarengi dengan gerakan operculum melambat pada menit 1620 lalu ikan pingsan pada menit 21-25. Pada perlakuan 800 ppm ikan mulai kehilangan keseimbangan di menit awal lalu stationer di menit 6-10 dan pada menit 11-15 gerakan operkulum ikan melambat, selanjutnya langsung pingsan pada menit 16-20.

Tabel 4 menunjukkan bahwa perlakuan ekstrak rebung bambu konsentrasi $800 \mathrm{ppm}$ memberikan pengaruh yang lebih cepat dibandingkan perlakuan $200 \mathrm{ppm}$ dan $400 \mathrm{ppm}$. Hal tersebut dapat dilihat dari waktu yang dibutuhkan ikan uji untuk mencapai tahap pingsan yang lebih cepat dibandingkan perlakuan lain.

Tabel 4. Pengamatan respon morfologis

\begin{tabular}{|c|c|c|c|c|}
\hline \multirow{2}{*}{$\begin{array}{l}\text { Waktu } \\
\text { (Menit) }\end{array}$} & \multicolumn{4}{|c|}{ Perlakuan } \\
\hline & Kontrol & $200 \mathrm{ppm}$ & $400 \mathrm{ppm}$ & $800 \mathrm{ppm}$ \\
\hline $0-5$ & & Normal & Bergerak aktif & $\begin{array}{c}\text { Kehilangan } \\
\text { keseimbangan }\end{array}$ \\
\hline $6-10$ & & Normal & $\begin{array}{c}\text { Kehilangan } \\
\text { keseimbangan }\end{array}$ & Stationer di dasar \\
\hline $11-15$ & & Bergerak aktif & Stationer di dasar & $\begin{array}{l}\text { Gerakan } \\
\text { Operkulum } \\
\text { melambat }\end{array}$ \\
\hline $16-20$ & Normal & $\begin{array}{c}\text { Kehilangan } \\
\text { keseimbangan }\end{array}$ & $\begin{array}{l}\text { Gerakan } \\
\text { Operkulum } \\
\text { melambat }\end{array}$ & Pingsan \\
\hline $21-25$ & & Stationer di dasar & Pingsan & \\
\hline $26-30$ & & $\begin{array}{l}\text { Gerakan } \\
\text { Operkulum } \\
\text { melambat }\end{array}$ & & \\
\hline $31-35$ & & Pingsan & & \\
\hline
\end{tabular}

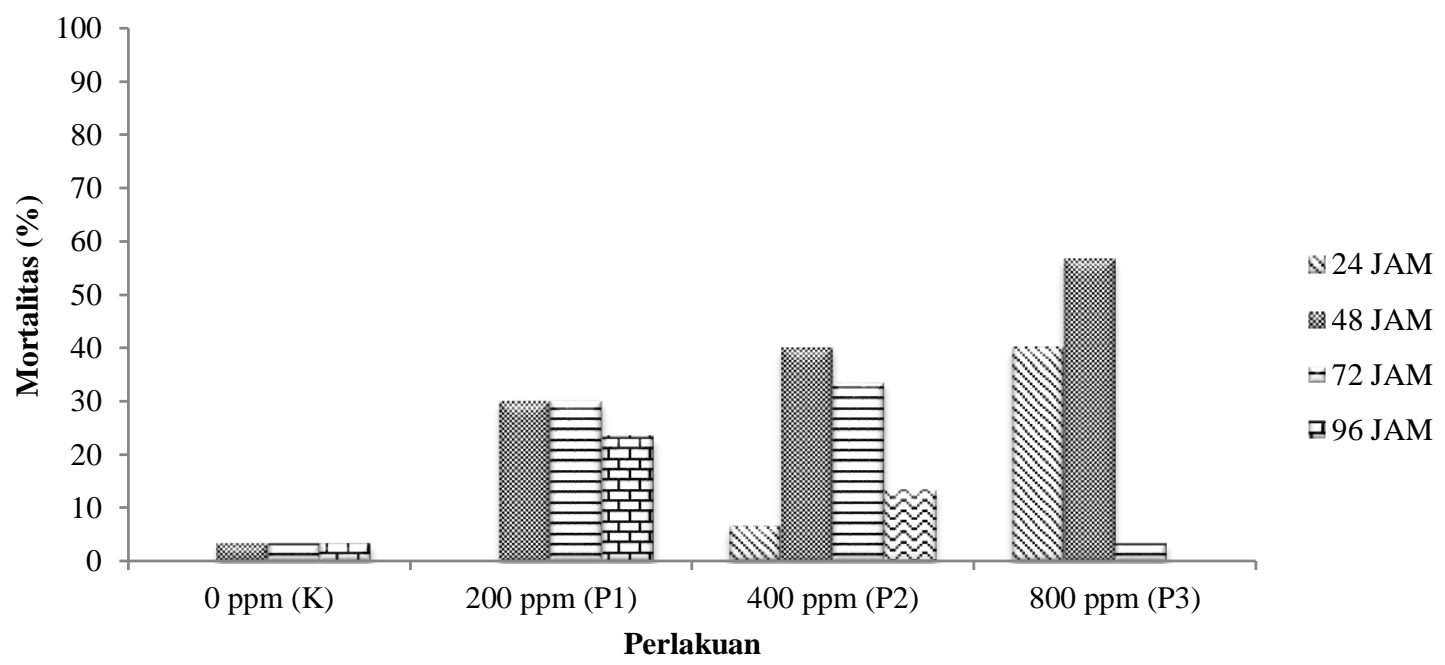

Gambar 1. Mortalitas Indikator $\mathrm{Uji}_{\mathrm{LC}} \mathrm{L}_{50}$ 


\section{Waktu Pemingsanan}

Waktu pemingsanan dicatat setiap 5 menit hingga ikan pingsan. Hal ini bertujuan mengetahui pengaruh konsentrasi ekstrak rebung bambu terhadap waktu yang dibutuhkan hingga ikan kehilangan kesadaran. Hasil pengamatan terhadap waktu pemingsanan dapat dilihat pada Gambar 2. Berdasarkan Gambar 2, waktu pemingsanan yang dihasilkan berbeda-beda karena pemberian kandungan ekstrak yang berbeda. Waktu pingsan yang paling cepat ditunjukkan oleh perlakuan ekstrak rebung bambu 800 ppm yaitu 16-20 menit. Waktu pingsan paling lama ditunjukkan oleh ekstrak rebung bambu 200 ppm yaitu 31-35 menit.

Waktu pingsan yang ditimbulkan akibat pemberian ekstrak rebung bambu dapat disimpulkan kurang efektif karena waktu yang ideal untuk memingsankan ikan adalah tiga menit. Berdasarkan hasil uji ANOVA pada taraf nyata 0,01 (99\%) perlakuan penambahan konsentrasi ekstrak rebung bambu memberikan pengaruh yang sangat nyata terhadap parameter waktu pemingsanan. Berdasarkan hasil uji lanjut Beda Nyata Terkecil (BNT) pada selang kepercayaan 99\% (Lampiran 7), diperoleh hasil berbeda sangat nyata antara perlakuan P3 dengan perlakuan P2 selanjutnya diperoleh hasil berbeda sangat nyata antara perlakuan P3 dengan perlakuan P1 dan P2 dengan perlakuan $\mathrm{P} 1$.
Lama Waktu Pingsan
Lama waktu ikan pingsan adalah
rentang waktu zat bahan ekstraksi yang mempengaruhi atau menurunkan kinerja sistem metabolisme pada ikan tersebut. Lama waktu ikan pingsan juga merupakan indikator untuk melihat keefektifan senyawa ekstrasi dalam memingsankan pada waktu yang lama. Hasil lama waktu ikan pingsan dapat dilihat pada Gambar 5.

Gambar 3 menunjukan lama waktu ikan pingsan setelah pemberian ekstrak rebung bambu. Hasil lama waktu ikan pingsan pada benih ikan lele sangkuriang kisaran $114.2 \quad-243.8$ menit. Hasil perhitungan ANOVA menunjukan bahwa pemberian konsentrasi rebung bambu memberikan pengaruh yang sangat nyata terhadap parameter lama waktu ikan pingsan pada benih ikan lele sangkuriang. Nilai lama waktu ikan pingsan terendah terdapat pada perlakuan P1 yaitu 114.2 menit dan perlakuan lama waktu ikan pingsan tertinggi terdapat pada perlakuan P3 dengan rata-rata 243,8 menit. Berdasarkan hasil uji lanjut Beda Nyata Terkecil (BNT) pada selang kepercayaan $99 \%$, diperoleh hasil berbeda sangat nyata antara perlakuan P1 dengan perlakuan P3, selanjutnya perlakuan P2 dengan perlakuan P3 dan diperoleh berbeda nyata Perlakuan P1 dengan P2.

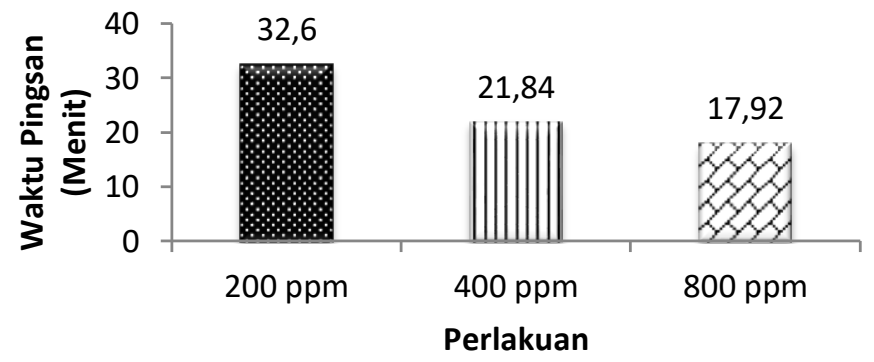

Gambar 2. Waktu ikan pingsan

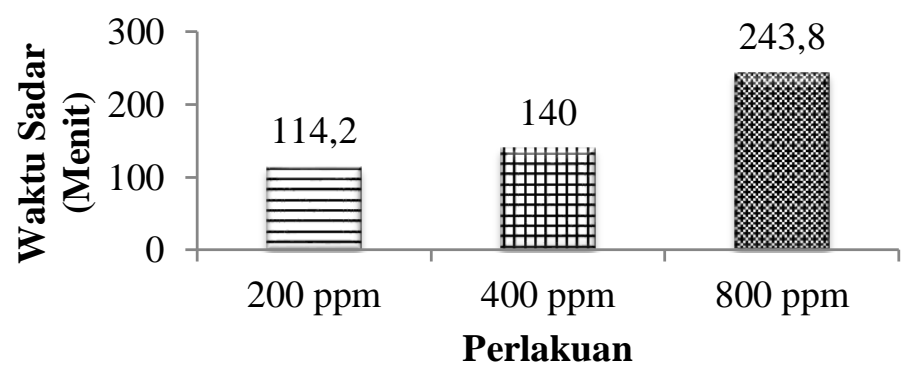

Gambar 3. Lama ikan pingsan 


\section{Kelangsungan Hidup}

Kelangsungan Hidup ikan ditentukan setelah benih ikan lele sangkuriang dipulihkan kembali dalam air dengan bantuan aerasi selama beberapa menit. Perlakuan ini dilakukan untuk mengetahui konsentrasi uji yang menimbulkan kematian yang tinggi pada ikan uji. Hasil nilai kelangsungan hidup dapat dilihat pada Gambar 4.

Gambar 4 menunjukkan tingkat kelangsungan hidup benih ikan lele sangkuriang setelah pemberian ekstrak rebung bambu dengan konsentrasi berbeda. Konsentrasi yang semakin tinggi maka kandungan alkaloid pada ekstrak semakin tinggi. Tingkah laku saat diberi ekstrak rebung bambu adalah ikan melakukan gerakan yang berlebihan dan akan mengalami shock yang dapat menimbulkan kematian pada ikan, hal tersebut karena adanya peningkatan asam laktat dalam darah. Hasil laju kelangsungan hidup (SR) benih ikan lele sangkuriang yang diuji berada pada kisaran $80-100 \%$ (Gambar 4). Hasil perhitungan ANOVA menunjukkan bahwa pemberian konsentrasi ekstrak rebung bambu berpengaruh sangat nyata terhadap kelangsungan hidup benih ikan lele sangkuriang. Nilai SR maksimum terdapat pada perlakuan Kontrol yaitu $100 \%$, diikuti P1 dengan rata-rata $93,33 \%$ selanjutnya P2 yaitu $83,33 \%$ dan perlakuan P3 sebesar $80 \%$.
Berdasarkan hasil uji lanjut Beda Nyata Terkecil (BNT) pada selang kepercayaan 95\%, diperoleh hasil berbeda sangat nyata antara perlakuan P3 dengan perlakuan P1, Perlakuan P3 dengan perlakuan kontrol, perlakuan P2 dengan perlakuan kontrol, selanjutnya diperoleh hasil berbeda nyata antara perlakuan P2 dengan perlakuan P1, serta terdapat hasil tidak berbeda nyata antara perlakuan P3 dengan perlakuan P2 dan Perlakuan P1 dengan kontrol.

\section{Kualitas Air}

Adapun parameter kualitas air yang diamati dalam penelitian ini meliputi suhu dan $\mathrm{pH}$. Data kualitas air selama penelitian berada pada kisaran optimal untuk kelangsungan hidup dan pertumbuhan (Tabel 5). Kualitas air selama penelitian berada pada kisaran yang sesuai dengan kriteria pemeliharaan benih ikan lele sangkuriang. Hal ini mengindikasikan bahwa kondisi lingkungan pemeliharaan termasuk pada kategori layak sehingga tidak berdampak negatif terhadap ikan uji. Kualitas air memegang peranan penting sebagai media tempat hidup ikan peliharaan dan menentukan keberhasilan suatu usaha budidaya.

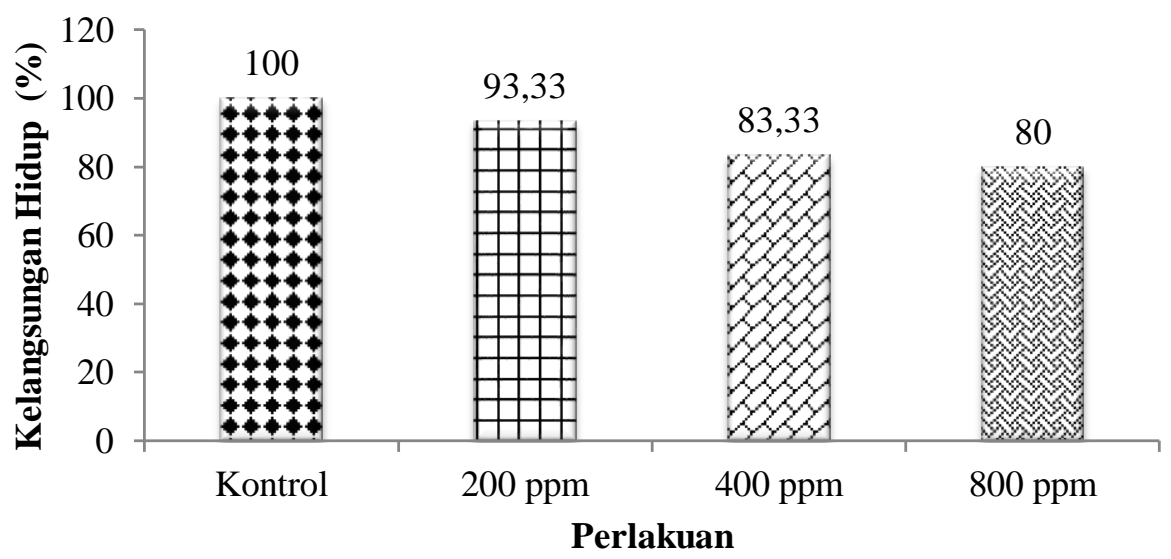

Gambar 4. Kelangsungan Hidup benih Ikan Lele Sangkuriang dengan konsentrasi ekstrak rebung bambu berbeda 


\section{KESIMPULAN}

Berdasarkan hasil pengujian ekstrak rebung bambu (Gigantochloa nigrociliata) sebagai anestesi terhadap kelangsungan hidup benih ikan lele sangkuriang (Clarias gariepinus) dapat disimpulkan bahwa pemberian ekstrak rebung bambu dengan konsentrasi yang berbeda memberikan pengaruh yang sangat nyata $(\mathrm{P}>0,01)$ terhadap tingkat kelangsungan hidup benih ikan lele sangkuriang (Clarias gariepinus). Serta konsentrasi ekstrak rebung bambu yang optimal didapatkan pada perlakuan P3 yaitu $800 \mathrm{ppm}$ yang dapat memingsankan ikan dalam waktu cepat.

\section{DAFTAR PUSTAKA}

Aminah NS, Chairul EW, Lestari A, Ahyar A. 1999. Senyawa aktif dari buah Lerak (Sapandius rarak De Candole) berpotensi sebagai pembunuh larva dan Nyamuk. Seminar Nasional Kimia Bahan Alam di Jakarta 24-25 September 1999.

APHA. 1998. Standart Methods for the Examination of Water and Wastewater. Fourteenth Edition. American Public Health Association. America.

Aras AK. 2011. Penggunaan Paparan Medan Listrik 10 volt dan Salinitas 3 ppt Terhadap Kinerja Produksi Ikan Botia Chromobotia macracanthus bleeker dengan Kepadatan Berbeda. [Skripsi]. Fakultas Perikanan dan Ilmu Kelautan. Institut Pertanian Bogor. Bogor.

Arliansyah. 2009. Perbedaan Pengaruh pemberian propofol dan penthotal terhadap agregasi platelet. [Tesis]. Semarang (ID): Program Pasca Sarjana Magister Ilmu Biomedik Dan Program Pendidikan Dokter Spesialis I Anestesiologi Universitas Diponegoro.

Choudhury DJ, Sahu JK, Sharma GD. 2012. Bamboo Shoot: Microbiology, Biochemical and Technology of Fermentation a Review. Indian Journal of Traditional Knowledge vol II pp 242-249.

Delmifiana B dan Astuti. 2013. Penagruh Sonikasi Terhadap Struktur dan Morfologi Nanopartikel Magnetik yang Disintesis dengan Metode
Kopresipitasi. Jurnal Fisika Universitas Andalas, Vol 2: No 3.

Effendi MI. 1997. Biologi Perikanan. Yayasan Pustaka Nusatama. Yogyakarta. 112 hal.

Effendie MI. 1979. Metode Biologi Perikanan. Yayasan Dewi Sri. Bogor. $112 \mathrm{Hal}$.

Gunn E. 2001. Floundering in the foibes of fish anestesia. Water Science and Technology 15(8):15-21.

Himawan. 2008. Budidaya Lele Sangkuriang. http://IndonesiaIndonesia.com /f/18253-budidaya-lele-sangkuriangclarias-sp/. 11.30. 23 Juni 2012

Husni H dan Esmiralda. 2010. Uji Toksisitas Akut Limbah Cair Industri Tahu terhadap Ikan Mas (Cyprinus carpio Lin). Jurusan Teknik Lingkungan, Universitas Andalas. Padang.

Khairuman dan K. Amri. 2009. Peluang Usaha dan Teknik Budidaya Lele Sangkuriang. PT. Gramedia Pustaka Utama. Jakarta.

Mckelvey D and Wayne K. 2003. Veterinary anesthesia and analgesia. Amerika: Occation the veterinarian. Mulyanto 1992).

Prasetyorini, Wiendarlina IY, Peron AB. 2011. Toksisitas beberapa ekstrak rimpang cabang temu lawak (Curcuma xanthorrizha Roxb) pada larva udang (Artemia salina Leach). Fitofarmaka. 1(2):14-21.

Rahardja, D. 1995. Pengaruh Anaestesisi tricme methanesulphonate (MS-222 sandoz) terhadap benih ikan mas (Cyprinus carpio L) karya ilmiah. Fakultas Perikanan. Institute Pertanian Bogor. Bogor.

Rochiman, K. 1989. Dasar Perancangan Percobaan dan Rancangan Acak Lengkap. Universitas Airlangga. Surabaya. Hal 53-104.

Royce, WF. 1972. Introduction to Fishery Sciences. Academic Press. New York. $351 \mathrm{p}$

Septiarusli IE, Haetami K, Mulyani Y, Danar D. 2012. Potensi Senyawa Metabolit Sekunder Dari Ekstrak Biji Buah Keben (Barringtonia asiatica) Dalam Proses Anestesi Ikan Kerapu Macan (ephinephelus fuscoguttatus). Jurnal Perikanan dan Kelauatan. Vol. 3:No.3, 
September 2012: 295-299. ISSN: 20883137.

Setiabudi EY, Sudrajat MD, Erlina dan Wibowo S. 1995. Studi penggunaan metode pembiusan langsung dengan suhu rendah dalam transpostrasi sistem kering udang windu (Panaeus monodon). Jurnal Penelitian Pasca Panen Perikanan, (84): 8-21.

Sujarwo W, Arinasa IBK, Peneng IN. 2010. Indigenous Knowledge on Gigantochloa hasskarliana (Kurz) Backer ex Heyne in Karangasem District, Bali, Indonesia. Magazine of American Bamboo Society 31(3):1415.

Wright GJ, Hall LW. 1961. Veterinary Anaesthesia and Analogesia. London (UK): Aquacultural Science.

Yanto, H. 2012. Kinerja MS-222 dan Kepadatan Ikan Botia (Botia macracanthus) yang Berbeda Selama Transportasi. Jurnal Penelitian Perikanan 1:1.

Zairin, M Jr, A. Yuniati, r.R.S.P.S. dan Sumantadinata, K. 2002. Pengaruh Lama Waktu Perendaman Induk Didalam Larutan Hormone 17 $\alpha$ Metiltestosteron Terhadap Nisbah Kelamin Anak Ikan Gapi. Jurnal Akuakultur Indonesia, 1: 31-35. 